European journal of American studies

$10-2$ | 2015

Summer 2015, including Special Issue: (Re)visioning

America in the Graphic Novel

\title{
Stateless within the States: American Homeland Security after 9/11 and Francis Lawrence's I Am Legend
}

\section{Eunju Hwang}

\section{(2) OpenEdition}

\section{Journals}

Electronic version

URL: https://journals.openedition.org/ejas/11117

DOI: 10.4000/ejas. 11117

ISSN: 1991-9336

Publisher

European Association for American Studies

Electronic reference

Eunju Hwang, "Stateless within the States: American Homeland Security after 9/11 and Francis

Lawrence's I Am Legend", European journal of American studies [Online], 10-2 | 2015, document 18

Online since 14 August 2015, connection on 08 July 2021. URL: http://journals.openedition.org/ejas/

11117 ; DOI: https://doi.org/10.4000/ejas. 11117

This text was automatically generated on 8 July 2021 .

Creative Commons License 


\title{
Stateless within the States:
}

\section{American Homeland Security after 9/11 and Francis Lawrence's I Am Legend}

\author{
Eunju Hwang
}

\footnotetext{
"We've come to know truths that we will never question: evil is real, and it must be opposed. Beyond all differences of race or creed, we are one country, mourning together and facing danger together.... And many have discovered again that even in tragedy-especially in tragedy -God is near....Our enemies send other people's children on missions of suicide and murder. They embrace tyranny and death as a cause and a creed. We stand for a different choice, made long ago, on the day of our founding. We affirm it again today. We choose freedom and the dignity

of every life."

- George W. Bush
}

\section{Introduction}

The President's State of the Union Address of 2002, a speech famous for condemning Iran, Iraq, and North Korea as constituting an "axis of evil," called forth national unity "beyond all differences of race or creed." The speech discloses a dual process of producing a national community: "othering" the outsiders and accentuating a common 
ground among national subjects. Bush emphasized the irreducible difference between Americans and their enemies through a binary opposition between good and evil while relativizing the differences within the United States.ii To oppose their "evil" enemies, Americans must unite as one people, one nation. On the other hand, Bush called attention to freedom as the creed that binds all Americans "beyond all differences" as a value inherited from the beginning of American history, the cultural root of the nation. In the speech, the War on Terror is sanctified as a way to realize the ideal of the nation, the destiny. The colorblind interpellation of national subjects, however, is deceptive in that the same rhetoric is used to deny the reality of racial profiling, surveillance, and aggressive law enforcement under the Patriot Act. Drawing a line between "us" and "them," between American and non-American, has never been as simple as Bush does in the speech, and certainly not all differences have been embraced as American.

2 Francis Lawrence's I Am Legend (2007) represents the hypocrisy of colorblind nationalism in post-9/11 America and symptomatically reveals the instability of the border between "us" and "them." I Am Legend, the third filmic adaptation of Richard Matheson's 1954 novel of the same name, presents a post-apocalyptic world where a man-made virus has decimated humanity, leaving only the infected who mutated into bloodthirsty, nocturnal monsters. The protagonist, Robert Neville, is a military scientist who tries to develop a vaccine in Manhattan, the "Ground Zero" of the outbreak. Neville becomes "legend" by sacrificing himself to save Anna and Ethan, survivors from Brazil, and by saving humanity with a cure for the virus. The extreme "otherness" of the infected, maximized with CGI, draws a clear boundary between humans and the monsters, between "us" and "them." Nevertheless, what is repressed in the process of othering the monsters erupts throughout the film and blurs the boundary; the monster at the end was once one of "us." The nonnegotiable and violent monsters who have almost no trace of humanity have been often considered as symbolic representations of terrorists due to the heavy reference to "Ground Zero" throughout the film, but I suggest the addition of another layer of meaning to the infected.

3 The infected in the film signify "the stateless within the state," national minorities who are contained within the 
territory of a nation-state but excluded from legal protection. In this sense, they are stateless yet still under the power of the state (Butler 34-35). According to Judith Butler, the stateless people, the "interiorized outsiders" (16), are periodically produced for the nation-state's need to "gain a legitimating ground for itself" (33) and contribute to the construction of a national community, giving a shape to the peoplehood. There are several examples in U.S. history, where the boundary between citizen and non-citizen has been constantly shifting, and non-citizens often fall into a state of statelessness. Religion, race, gender, and class have played critical roles in dictating where to draw the line between citizenship and non-citizenship. Residency was also an important factor, though not in the case of the Native Americans, who remained stateless, neither citizens nor foreigners, until 1924. However, not all citizens were considered "American" enough, as is evidenced by the case of the Japanese relocation during World War II. Among the 120,000 people of Japanese ancestry in the camps, two-thirds were American citizens, and these potential "spies" and "enemies" were forced into a state of statelessness between 1942 and 1945. The infected in I Am Legend embody what those Japanese Americans experienced as "prisoners of their own government in their own country" (Tashima 8). The infected symbolize those whom the post-9/11 United States has jettisoned as its enemy but contained within its borders, from illegal immigrants to American citizens whose loyalty to their nation is questioned. ${ }^{\text {iii }}$

4 The rich critical and compositional genealogy of I Am Legend shows how the infected monsters have been imagined and reimagined according to the racial politics of the time, at the same time suggesting why Lawrence's I Am Legend is such a relevant text for post-9/11 America. The vampires in Matheson's novel, as Kathy Davis Patterson argues, are the manifestation of "white racial anxiety in the 1950s America," and Neville's demise "serves as a powerful metaphor for the inevitable failure of segregation" (25). Patterson's reading reflects the social context of the 1950s when the increasing black population in suburban California encountered strong anti-black hostility on the part of white residents; the white residents of Compton, the setting of the novel, employed every possible means to stop blacks from moving in (Sides 585-586). Christian Wenk takes a similar line of analysis when he suggests the depiction of vampires in the novel "carries a strong 
undercurrent of anti-Semitism" (219). Wenk's insight reveals there was still much anxiety about Jews after World War II. As Johan Höglund points out, what makes the novel stand out among other sci-fi novels of its time is the subversive ending which reveals Neville as the real monster, not the vampires (68-69). This subversive quality survives in The Last Man on Earth, the first film adaptation produced in 1964, though all racial references from the novel are removed. In this first adaptation, Bill Cortman, Neville's Jewish archenemy, is now an attractive blond man played by an Italian actor. Any direct connection between monsters and specific racial or ethnic groups could be considered unwise during the peak of the Civil Rights Movement. The mutant vampire militia's black suits in The Last Man on Earth suggest that, given the context of the racial structure in the 1960s, the vampires were representative of fear and anxiety regarding black empowerment.

5 In The Omega Man, the second adaptation produced in 1971, Matheson's vampires gave way to albino mutants in black robes and hoods. As Adilifu Nama points out, with their dark glasses, Molotov cocktails, and condemnation of Neville as the "devil," the albino mutants have "startling similarities to the Black Power radicals" and the "Nation of Islam's extremist articulation of black nationalism" (48). The interracial relationship between Neville and Lisa seems to endorse equal rights for black people, but the relationship functions only to emphasize Neville's "white male assurance" (Nama 51). This adaptation's climactic ending differs from the novel's in that Neville is portrayed as a self-sacrificing hero for humanity. Charlton Heston's physiology of Neville, similar to Matheson's original conception, as a man with bright blue eyes and blond hair, as well as his proud presentation of his "genuine 160-proof old Anglo-Saxon blood" as a cure for the deadly disease, served as the dominant image of Neville until Will Smith's casting in 2002. Only white actors-Tom Cruise, Mel Gibson, and Arnold Schwarzenegger-were under consideration for the role of Neville until the incident of 9/11 (Hughes 128).Therefore, casting Will Smith as Robert Neville deserves critical attention.

6 In this context, casting Will Smith as Robert Neville deserves critical attention. Sean Brayton argues that Smith's presence as a "black Christ" (69) promotes multiculturalism because in the film, "infection is 
synonymous with whiteness, whereas survival is associated with racial and ethnic difference" (72). This understanding of the black-white relationship, however, does not speak to the reality of post-9/11. The coding of a black hero has to be understood in the context of colorblind nationalism that interpellates a black citizen as American rather than as racial minority to cover up profound racism in post-9/11 America. Janani Subramanian argues that I Am Legend exemplifies the dual process of containing blackness and weakening cultural politics; according to her, the film "exemplifies and complicates this 'colorless' American nationalism" (37) because Smith's star image forecloses the "potential political significance of blackness after 9/11," not challenging "(white) nationalist norms" (45). I propose building on her insight to reexamine Will Smith's casting beyond the black-white logic of biracialism.

7 Colorblind nationalism in I Am Legend must be understood from the dynamic perspective of a multiracial framework. Claire Jean Kim's theory of the "racial triangulation," though its major concern is limited to Asian Americans, provides a useful insight to broaden Subramanian's perspective to include other racial groups. Kim shows that the racialization of each minority group is different from that of other groups but at the same time always associated with them. For example, according to Kim, Asian Americans have been relatively valorized as model citizens, thus superior to blacks but inferior to whites, while also ostracized as being more foreign than blacks ("The Racial Triangulation" 107). Kim argues that the racial triangulation functions to maintain the status quo of racial hierarchy. A biracial framework simplifies the complexity of multiracial society and misses the dynamics between different racial, ethnic, and religious groups, especially when some of them are antagonized as the internal enemies against the rest.

s Lawrence's I Am Legend, at one level reflecting the commitments of colorblind nationalism, attempts to erase all racial markers from the infected. Still, movie critics noticed and commented on the skin color of the infected. For example, Bernice M. Murphy acknowledges their whiteness, but does not offer any explanation for their "notably white complexions" (33). Hantke argues that the film "disavows racial difference altogether," without privileging the whiteness of the infected (184), though he does not provide any further discussion about implications. 
I propose that the pale skin of the infected is a mask that hides the monsters' metaphorical status as nationally abject, representing everything that is not American.iv Behind the pale skin, in the form of extremely unhuman morphology and kinetic movements, there lies the fear of racial, ethnic, and religious others, the "foreign within."

9 In the context of colorblind nationalism, the "otherness" of the infected in $I$ Am Legend cannot be openly characterized as in terms of racial difference. The racial difference between Americans has to be repressed, while the difference between Americans and non-Americans has to be maximized and upheld in order to achieve the ideal of America as one nation. In the film, all racial markers are replaced by geographical markers to suggest the symbolic meaning of the infected. ${ }^{v}$ Despite the fact that they are stripped of characteristics often associated with racial otherness, the symbolic meaning of the infected as stateless people within the United States is revealed by the filming location. The virologist analogy also operates as a dividing mechanism between human and non-human, "us" and "them." In other words, the "sick" mutants are those who have to be excluded for the moral and economic health of the nation while the "healthy" subjects are welcomed to the survivors' colony. Even though the film represses more overt forms of racism, its colorblind racism becomes apparent through Neville's seemingly "innocent" virologist analogy.

\section{Homeland Security after $9 / 11$ and Stateless People within the State}

10 Post-9/11 America produced thousands of stateless people within its borders; this was justified as necessary for providing homeland security. According to Amy Kaplan, the enforcement of homeland security supports "the resurgent nativism and anti-immigrant sentiment and policy" and "polices the boundaries between the domestic and the foreign not simply by stopping aliens at the borders, but by continually redrawing those boundaries everywhere throughout the nation, between Americans who can somehow claim the United States as their native land, their birthright, and immigrants and those who look to homelands elsewhere, who can be rendered inexorably foreign" ("Violent Belongings" 8-9). People who cannot claim the United States as their homeland can be labeled foreign, according to Kaplan, because naturalization and 
citizenship have turned out to be insufficient grounds for claiming domestic status.

${ }_{11}$ Arabs and Muslims were the first groups of people to fall victim to massive arrests, detentions, and FBI interviews after 9/11. Louise A. Cainkar, the author of Homeland Insecurity: The Arab American and Muslim American Experience After 9/11, contends that the U.S. government reconstructed Arabs and Muslims living in the United States as "people who were not really part of the American nation... and thus not fully eligible for the nation's package of civil and constitutional rights" (111). The respondents of Cainkar's interview expressed their fear of government because they perceived that "the rule of law did not apply to them," and "[t]heir citizenship...had been rendered meaningless" (116). vi Arabs and Muslims experienced a sense of "homeland insecurity" as a result of being considered foreign and denied any civil and constitutional rights. This reveals the real danger of colorblind nationalism in a post-9/11 America, where the concept of individuals as united "beyond all differences of race or creed" was built upon the systematic exclusion of "others" produced by racial, ethnic, or religious profiling.

12In 2003, Michael Chertoff, the former Secretary of Homeland Security (February 2005-January 2009), urged the government to take harsher measures for ensuring homeland security, saying:

the government's actions after September 11 reflected a consciousness of history and of the historical moment. Excesses of the past were not repeated. A balance was sought and, I hope, achieved. That balance was struck in the first flush of the emergency. If history shows anything, however, it shows that we must be prepared to review and if necessary recalibrate that balance. We should get about doing so, in the light of the experience of our forebears and the experience of our own time.

13 Under the thin disguise of civility, what Chertoff was actually seeking were the "excesses of the past." Though he called the internment of Japanese Americans during World War II the "most infamous example," it is not difficult to see his willingness to repeat past mistakes. After the election, he took all of the "extraordinary" measures he named in the op-ed piece, including raids, detentions, and deportations; he even constructed a 700-mile fence along the Mexican border and made a contract with Boeing to build "virtual fences" made of cameras and radar systems. The Department of Homeland Security (DHS) assumed the huge responsibility of preventing terrorism by securing the border and finding and deporting illegal immigrants.

14The War on Terror essentially became the War on Immigration in all but name. As Edward Alden stated, 
"immigration and terrorism have become intertwined to the point where it has become almost impossible to separate them" (292). Former DHS attorney Asa Hutchinson justified the shift: "If we cannot protect our border from economic migrants, we cannot protect our border from terrorists" (quoted in Alden 257). This war, however, had to be fought within the United States, redrawing boundaries within the borders. James A.R. Nafziger observed that arrests by the U.S. Immigration and Customs Enforcement (ICE) "increased ten-fold between 2002-2007," and there occurred an "alarming rise of anxiety about foreigners in this country and attacks on them," exemplified by a 23 percent increase in anti-Latino hate crimes between 2003 and 2005 (558).

${ }_{15}$ Chertoff would argue that only illegal aliens were targets of the DHS, but in the process of their enforcement, immigration laws also affected legal residents and U.S. citizens by creating a large number of stateless people within the nation. This occurred because the immigration process almost always involved racial discrimination and racial profiling, and also because many individuals knew people-relatives, friends, neighbors, or colleagues-whose lives were directly affected. Thirty-three percent of the American population is comprised of foreign-born individuals or the children of at least one foreign-born parent. According to the U.S. Census Bureau (2009), 36.7 million of the nation's people are foreign-born, and 33 million are native-born with at least one foreign-born parent (Kandel). The estimated number of illegal immigrants in the United States in 2011 was 11.5 million (Hoefer). The fact that thousands of children born in the United States, for example, were separated from their parents by detention or deportation proves how certain individuals, despite citizenship, have been actively forced into a state of bare existence by the law instead of being protected by it ("Overraided, Under Siege" iv).

${ }_{16}$ It was not a coincidence that I Am Legend was written and produced at the time when Chertoff initiated the toughest immigration law enforcement and Congress passed the Border Protection, Anti-terrorism and Illegal Immigration Control Act of 2005 (H.R.4437, the so-called "Sensenbrenner Bill"). This bill, that would not only detain or deport undocumented immigrants as criminals but also make it a felony for U.S. citizens to provide immigrants any humanitarian help, triggered several large-scale immigration reform protests throughout the United States 
in 2006. The Sensenbrenner Bill revealed the fear of losing the homeland to inside "foreigners" and the nostalgic desire for a "lost" homeland that never existed in the first place.vii

${ }_{17}$ The post-apocalyptic world of I Am Legend reflects this problematic sentiment, portraying a colorblind version of American "apocalyptic sensibility" (Berger 133) inherited from the first English settlers and persisting in the form of "nostalgia for a pre-urbanized, preindustrial America" (Berger 135), or the desire to break with the past and build a new society. The survivors' colony made of "healthy" people, far removed from the jungle of the city haunted by the "sick" monsters, epitomizes nostalgia for the homeland before it was lost to the "foreign" within.

${ }_{18}$ To explore how colorblind nationalism functions in Lawrence's I Am Legend, it is important to compare its representation of the infected monsters to those of earlier script versions, which were dropped after 9/11, and to the earlier version of the film starring Charlton Heston. Mark Protosevich's and John Logan's pre-9/11 scripts differ in significant ways from the post-9/11 Akiva Goldsman script ultimately used for Lawrence's I Am Legend.viii The theatrical release of I Am Legend has removed all racial demarcations from the infected. In Protosevich's script, the infected have pale skin, like those in Lawrence's film, but they adorn their bodies with "tribal markings and jewelry," and Cortman, the leader of the infected who builds a colony in the subway tunnels of San Francisco, is compared to a "tribal warlord." They are cannibalistic because there is a lack of the non-infected human food they prefer to eat. This group of "hemocytes," as Protosevich terms them, has given up its nomadic life and instead tries to settle down, raising human children as livestock. Similarly, in Logan's script, the infected are animalistic but intelligent monsters, "sheathed like Arab Bedouin tribesmen," and Neville is like a Western hero. He toasts to the portrait of John Wayne hanging on the wall in his inner-city den, a suite in the Ambassador Hotel, and becomes "Gary Cooper in High Noon" when he fights all alone against a horde of the bloodsucking "Warriors," which tracked him to a ghost town in the desert.

${ }_{19}$ Color does not matter in the world of I Am Legend; nevertheless the film could be considered a more dangerously racist text than Matheson's original novel in which Neville, with bright blue eyes and blond hair, openly calls the vampires "black bastards." In Lawrence's I Am 
Legend, all of the racial markers of clothing, adornment, and behavior give way to geographical markers, and all references to other genres such as Westerns and action films disappear. Instead, the film finds its major inspiration in the serious science fiction movies of the 1960s and 1970s, which reflected society as an allegory and remained "palatable" (Goldsman). Under its colorblind surface, I Am Legend is an allegory of post-9/11 America, which hides a fear of the racialized "enemies within" and desire to reclaim its homeland diseased with the "foreign" monsters.

\subsection{From California to New York: Geographical Markers of Difference}

Lawrence's I Am Legend is radically different from Matheson's novel in several ways. First, it transforms Neville from an average man of the 1950s who happens to be the last human being on earth into a black military scientist who saves humanity by sacrificing himself. Second, it also transfers the entire setting from Compton, a suburban town in California, to Manhattan, New York City. According to Goldsman, he and Lawrence made this decision because New York is an "iconic landscape to evacuate" as it is "never still and never quiet." However, New York proves more than a visually stunning landscape: there is a strong reference to 9/11 when Neville says that he cannot leave New York as it is "Ground Zero." With its long history of immigration and status as a global city, New York is rich with examples of drawing and redrawing boundaries between people.

${ }_{21}$ According to a 2010 report by the New York State Comptroller, in 2008 foreign-born people comprised 36.4 percent of New York's population and accounted for 43 percent of the city's workforce, including 285,000 commuters (Dinapoli and Bleiwas 1-2). This number does not include people born in Puerto Rico, U.S.-outlying areas, or born to U.S. parents abroad. It also found that 48.5 percent of New York's population over five years of age speak languages other than English at home (U.S. Census Bureau State and County Quick Facts, data from 2007-2011). Despite its reputation as a "melting pot," New York is one of the most segregated cities in the United States, "an archipelago of distinct groups, with distinct white, Latino and Asian districts and little sign of movement between them" (Homberger 160). Eighty-five percent of Census blocks had the "same predominant racial/ethnic population in 2010 as they did in 2000" ("New York City 
Demographic Shifts, 2000 to 2010"). Nine of the 55 New York neighborhoods defined by the U.S. Census Bureau have immigrant populations of more than 50 percent of the neighborhood's total, and another ten have immigrant populations of between 40 and 50 percent (DiNapoli and Bleiwas 2).ix

${ }_{22}$ In making New York the shooting location, Lawrence placed I Am Legend at the center of this spatialized dynamic of differences, where the boundaries of inclusion and exclusion keep shifting and crossing one another. The shooting locations reveal what the infected-the abject of the post-9/11 American identity as a unitary wholesymbolize: non-American, and therefore condemned, populations. The post-apocalyptic New York is the "thirdworldified" metropolis of the First World. Time Square that has become a jungle in the opening scene manifests the old fear of New York as a diverse, immigrant city. "Thirdworldification" is a term Priscilla Wald uses to explain how "outbreak narratives"-both fictional and nonfictional accounts of communicable diseases-relate a certain disease to its foreign origin and constitute it as the "incarnation of a timeless and diseased 'Third World' leaking, through microbes, into the metropolises of the 'First World'....threatening to transform a contemporary 'us' into a primitive 'them'" (45). Immigrants, who lived in the "thirdworldified" impoverished areas, are often associated with outbreaks of infectious diseases (Wald 43-45). The geographical landscape of I Am Legend is reflective of the fear of "thirdworldification" of the United States and the history of New York as the oldest and biggest gatekeeper to stop the "sick" from entering the United States and enforce quarantine.

${ }_{23}$ The tricky process of (re)drawing boundaries and repressing uncertainties about those boundaries is effectively shown in the evacuation scene at South Street Seaport. The evacuation scene is an uncanny reminder of the dreadful eye examinations performed at Ellis Island in the early twentieth century. As seen in Figure 1, newly arrived immigrants had to undergo medical examinations, including eye exams, upon their arrival. Nearly half of those who had to be examined further suffered from an eye disease called trachoma ("Medical Examination"). This eye examination was a dreadful moment for immigrants: if the doctor diagnosed them with trachoma, they would be sent back home. When a child older than twelve was refused entry to the United States because he was sick, he was sent 
back home alone. If the child was younger, one of the parents had to return home with the child.

Figure 1

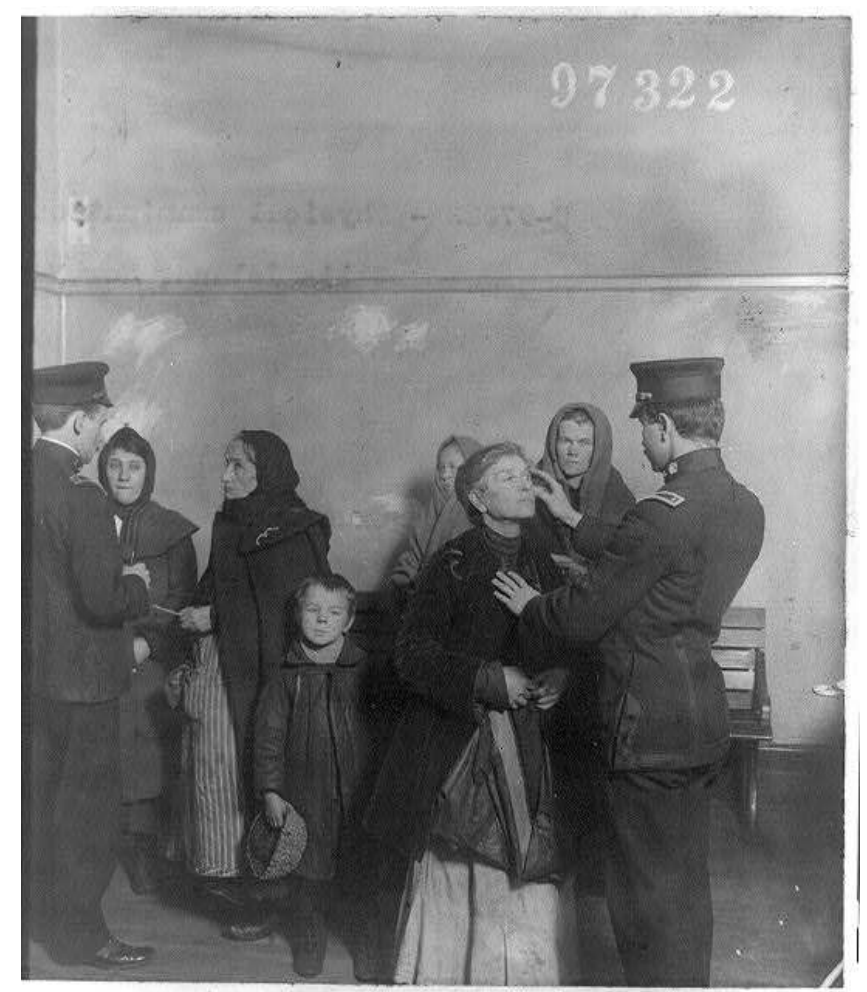

Physical Examination of Female Immigrants at Ellis Island, New York City. 1911. Library of Congress, LC-USZ62-40103.

${ }_{24}$ In the film, when Manhattan is quarantined to stop the virus from spreading, those who try to leave the island are stopped by the explosion of bridges. The barricade on the pier symbolizes a receding border between those whom the state will continue protecting and those who will be contained yet unprotected; the quarantined New Yorkers will be the stateless within the state. The evacuation scene exposes the precariousness of this new border: when Neville's wife's eye is scanned and determined to be unhealthy, Neville orders the soldier to scan her again, and when the second scan is negative, she is allowed to pass through the barricade (see Figure 2). This detail suggests that eye scanning can be an untrustworthy means of determining who is in and who is out.x Right after the Nevilles pass the barricade, an infected woman begs Neville to take her child with them, and the camera hesitates on her as if the image is haunting Neville's mind. A mother with a daughter like his own is now behind the barricade; whether she dies or mutates, she will never be the same human being. The image of the woman shedding 
bloody tears in despair haunts Neville's memory because her image is what is repressed in the process of creating the infected as abject subjects. Her bloody tears prove that she is infected and, at the same time, that she is still human, able to cry.

Figure 2

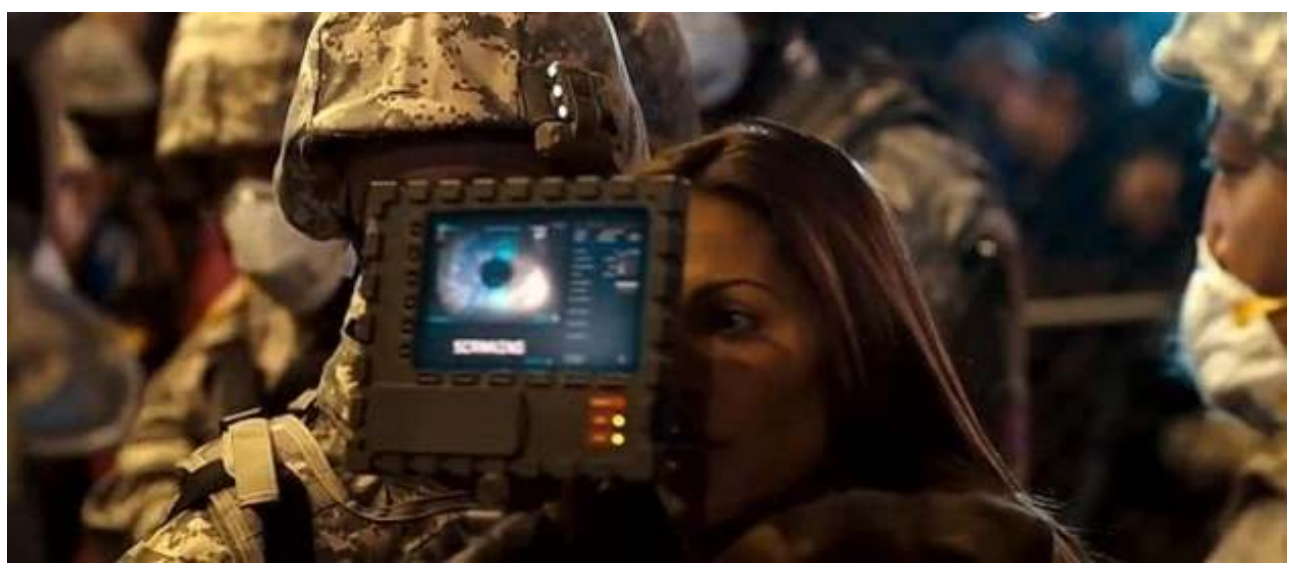

Scanning the eye to check for viral infection in I Am Legend.

${ }_{25}$ If the evacuation scene symbolically shows how the infection has created a new border between people, and further shows how that border is an arbitrary line, then the Meatpacking District as the chosen location for the "hive" of the infected adds multiple possibilities for interpreting their symbolic meaning. The Meatpacking District, once an area for blue-collar meatpacking laborers, gay bars, drug dealing, and prostitution, is now one of the trendiest neighborhoods in New York, with its hip restaurants, expensive clubs, and boutiques. It was not until the 1990s that gentrification started dramatically changing the neighborhood's landscape. Real estate pressures drove the meatpackers out as they could not afford the skyrocketing rent. Still, even at the time that I Am Legend was made, gentrification had not completely eradicated the Meatpacking District's image as a site for slaughterhouses, immigrant butchers in bloody white coats, and gay bars and sex clubs. ${ }^{\mathrm{xi}}$

${ }_{26}$ The hive in the Meatpacking District relates the infected to what the setting had been traditionally associated with: filth, blood, disease, the abject, the "foreign." The infected are those who were jettisoned from the Meatpacking District due to gentrification. What was once a neighborhood for poor, immigrant, blue-collar workers has now been sanitized and tamed for yuppies, all of its former 
occupants evicted. This can be evidenced simply by the long list of fancy international restaurants, which showcase a "palatable" version of multiculturalism. The array of ethnic restaurants, commercialized and packaged as consumable, celebrates diversity while suppressing the reality of ongoing racism. However, the "thirdworldified" Meatpacking District in I Am Legend is reclaimed by its former occupants and is filled with the stench of history.

${ }_{27}$ As the setting of I Am Legend, the Meatpacking District functions as a geographical marker to emphasize the "otherness" of the infected. It provides a perfect habitat for those who symbolize the poor (in ragged clothes with bare feet), the homeless (squatting together in a deserted building), the junkies (crazily blood-thirsty), the sexual "aberrants" (no monogamous heterosexual relationship is suggested, at least in the theatrical version), xii the foreigners (non-English speakers), the immigrants who remain "foreign" (who eat a disgusting diet), and the illegal immigrants who hide in the dark (resonating with the ICE attacks on meatpacking factories all over the country).xii The "Darkseekers," as Neville terms the infected, are the manifestation of everything that post-9/11 America did not want to acknowledge as part of itself. The sidewalk overhangs a dark interior that once kept meat fresh from the heat, turning it into a perfect location for the infected, who avoid the light. The carcass of a deer and its spilled blood on the floor of the building remind us of the building's original use.

${ }_{28}$ The Darkseekers, or "hemocytes" as they are referred to in the script, are hybrid creatures, somewhere between vampires and zombies. Traditionally, vampires-whether they signify disease-carrying foreigners or exploitative aristocrats-symbolize outsiders who contaminate "our" blood and are parasitic to "us." The image of the vampire, however, has evolved throughout history according to the social context in which vampires are imagined. From a romantic seducer to a suffering inquirer of his raison d'être, from a "vegetarian" to an assimilationist, the image of the vampire has perpetually changed. Kevin J. Wetmore argues that some post-9/11 vampires represent terrorists who are "fast moving, dangerous, monstrous beasts just one step above hillbilly and zombie" (165). On the other hand, zombies stand for those who have lost their souls, whether they are slaves under a spell (White Zombies) or the flesheating walking dead (Night of the Living Dead). ${ }^{\text {xiv }}$ They 
reflect the fear of losing one's selfhood, thereby signifying "us" without the "self." As many critics have suggested, after $9 / 11$, zombies rapidly evolved into running zombies, as in the case of 28 Days Later. Wetmore argues that zombies in post-9/11 films "represent complete depersonalization" and "they make an excellent metaphor for terrorists" because they "cannot be reasoned with, cannot be negotiated with" (159-160). The generic differences between vampires and zombies, however, disappear in $I \mathrm{Am}$ Legend.

${ }_{29}$ The combination of these two different monstrosities in $I$ Am Legend creates a monster that is neither a complete outsider nor an insider. They are the outsiders inside the border-the stateless within the state-and destabilize the border between "us" and "them." Although nocturnal and bloodthirsty like vampires, the infected in I Am Legend do not have the romantic or aristocratic qualities that we often associate with vampires; they live in rags and dirt, have lost their language capabilities, and swarm like zombies. Stripped of the supernatural qualities and aristocratic lifestyle of vampires, they represent what zombies often symbolize: race and class rioters. They symbolize illegal immigrants, whom an increasing number of American citizens consider parasitic, dangerous, and unassimilable after 9/11. The monsters in I Am Legend are also representative of those who used to be "us" but turned against "us" like mindless terrorists: they climb walls, cross the borders of ultraviolet light and explosives, break through the ceiling of the apartment, and throw their bodies at Neville.

30 The survivors' colony revealed at the end of the film, with its high fences and armed military forces that can protect humanity from the hybrid monstrosities, is a great contrast from the "thirdworldified" city. However, a deleted scene suggests that the film erased an obvious sign that could suggest further parallels between post-9/11 colorblind, American nationalism and the film: ice (clearly alluding to the governmental organization ICE). While with Anna and Ethan in the Metropolitan Museum of Art, Neville comes up with an idea for how to kill the virus. Hurrying home, he exclaims twice that he needs ice. A great risk was taken in deleting this scene, because in the following scene, the audience would not understand why an infected female, a kidnapped test subject, is suddenly lying in ice. This deletion may suggest the director's effort to remove any 
clue that might pin down one specific group of people as the infected, thereby making the film less controversial. As previously discussed, ICE was very active in raiding homes and worksites to arrest and deport undocumented immigrants around the time when I Am Legend was made. According to Nafziger, "Arrests by ICE, too often involving racial profiling, increased ten-fold between 2002 and 2007, reaching record numbers in 2008" (558). In the film, in the mountains of Vermont, where ice can keep the virus from spreading, humanity claims a new homeland, the "city upon a hill."

\subsection{Survivors: Searching for the Homeland}

31 New York City, or "Ground Zero," is where Neville loses his war with the virus. It is also where he loses his family, but he insists on staying there, not simply because he owns a fancy townhouse facing Washington Square, but, ironically, because his home has been forever lost to him before his very eyes. For Neville, New York has become "Ground Zero," the lost homeland. It seems that he owns the entire city during the daytime, but he is disowned from everything at night, when the streets belong to the infected. Neville's story of his lost homeland, and his effort to recover it, reverberates with the post-9/11 American phenomenon of homeland security. The term "homeland," which according to Kaplan was never used by political leaders before 9/11, conveys a sense of nativism, and thus excludes many people who live in the United States but locate their homeland elsewhere ("Homeland Insecurities" 87). However, because of the exclusion, the homeland is a "fundamentally uncanny place, haunted by all the unfamiliar yet strangely familiar foreign specters that threaten to turn it into its opposite" (Kaplan, "Violent Belongings" 9). Kaplan criticizes the notion because it makes anyone with such "dual identifications" become targets of suspicion and potential threats to national security ("Homeland Insecurities" 87). These people who make their home in the United States but look elsewhere for their homeland are the "unfamiliar but strangely familiar foreign specters" who blur the border between "us" and "them." Neville exists in a world after the uncanny "foreign specters" have wiped everything out and claimed the streets as their own, and the driving force behind Neville's ceaseless pursuit of a vaccine is the nostalgic yearning for his lost homeland. He tries to recover it by turning the infected into humans again, by going back to the time before the virus took everything away from him. 
32The virologist image, by drawing the border between the "healthy" and "sick" as analogous to good and evil, "us" and "them," is not as innocent as it seems. The film risks ridicule when it makes Anna ignorant of Bob Marley even though she knows his son, Damian Marley, giving Neville a chance to explain who Bob Marley is so that he can draw an analogy between Marley and himself:

He had this idea. It was kind of a virologist's idea. He believed that you could cure racism and hate. Literally cure it...by injecting music and love into people's lives. One day, he was scheduled to perform at a peace rally. Gunmen came to his house and shot him down. Two days later... he walked out on that stage and sang. Somebody asked him why. He said, "The people who are trying to make this world worse are not taking a day off. How can I?" Light up the darkness.

In the passage, Neville reiterates Marley's popular image in the United States, which was constructed by record companies in the 1980s and 1990s. Marley's album Legend was released three years after his death by Island Records. To erase Marley's rather unpopular image as a 1970s revolutionary, the record company promoted Marley as a mystic who embodied the "vision of racial harmony built on simple universalist ideals mystically removed from the history of race relations in the United States" (Stephens 142). This strategy was successful because it "helped to preserve a North American identity built on the integration of racial differences into one unified national body politic" (Stephens 142). Through the analogy, Neville makes himself a legendary figure much like Marley, whose music cures all by uniting differences and bringing about harmony.

34The seemingly harmless analogy, however, is logically flawed. It compares the infected to those whose racism Marley tried to cure with his music. The infected, symbolizing the stateless, "foreign" people who are denied legal protection often based on racial, ethnic, or religious profiling, make a wrong pair with Marley's "patients." Neville's cure, in fact, means to turn the infected back into humans-to turn "them" into "us." If the infected are national others in this time of colorblind American nationalism, Neville's serum is not a cure for racism, but a cure to solve the problem of the post-9/11 irreconcilability between a desirable multicultural America and increasingly obtrusive homeland security measures by eradicating differences, blending all forms of otherness into hypernational Americanness.

${ }_{35}$ Neville's violence, which seems to contradict his expressed desire to save the infected, is justified by the monsters' complete loss of humanity. On the night when the infected attack Neville's house, Neville, cornered behind a 
glass wall, the last barrier, offers his help: "I can save you. I can help you. You're sick...I can fix this. I can save everybody." Neville, however, cannot reason with the infected because they are non-comprehending, with neither human intelligence nor language. Driven only by animal instinct to kill, the infected keep attacking Neville and leave him with no choice but to die with them to save humanity. This version of Neville's death leaves no hope for a peaceful means to achieve one nation without internal divisions. The binary structure of "us" and "them," good and evil, persists until the end, even though there has been some divergence from this pattern in the middle of the film as in the case of the South Street Seaport scene.

${ }_{36}$ Throughout the film, Neville firmly believes that the infected have completely lost their humanity, and whenever there is a sign that betrays his belief, it is repressed. After observing that the alpha male exposed himself to sunlight when Neville caught an infected female for a human trial, he states, "it's possible decreased brain function...or the growing scarcity of food is causing them to...ignore their basic survival instincts. Social de-evolution appears complete. Typical human behavior is now entirely absent." In a deleted scene, visiting the spot where he was caught by the infected, he denies the possibility that the infected are intelligent enough to use the same trick that he does. Neville tells Anna that they have "no higher brain function. They don't play, don't hate, don't love. They can't." Just as he gave the cold shoulder to an infected mother who begged him, crying, to take her child, he does not want to face the fact that there is something human in the infected. The scene had to be deleted, and any doubt about the monsters' extreme otherness had to be repressed as much as possible because the border between human and the infected, good and evil, "us" and "them," had to be maintained for the commercial success of the film.

37The theatrical ending in which Neville becomes a Christlike hero and sacrifices himself for humanity suggests that the war should continue between "us" and "them" until they all become like us, or are altogether annihilated. Like a suicide bomber, Neville sacrifices himself to kill all of the infected in the lab. The boundary between humanity and monstrosity, which is momentarily blurred when Neville shifts the addressee from "you" to "everybody" (Boyle), is firmly drawn again by antagonizing the infected, who refused to undergo "conversion." Neville's act of throwing himself toward the infected with an unpinned grenade, 
mirroring the alpha male's aggressive thudding of the glass wall against his head, is reminiscent of suicide bombers. The scene symptomatically reveals the danger embedded in the War on Terror that turns the warrior into a "monster" in the process. The theatrical version of Neville's death scene manifests what Wetmore calls the fear "not just of Other but what Self becomes in response of other" (5).

${ }_{38}$ The original ending of the film, considered not commercially promising and replaced before the theatrical release, is called the "alternate ending," released in a DVD set. The alternate ending is closer to that of Matheson's novel, which breaks down the binary between "us" and "them." In the alternate ending, the border between human and non-human, hero and villain, is disturbed and made unclear. Neville realizes that the infected can communicate, feel emotions, and have a social structure, and most of all that they do not want to be "cured." Hantke argues that this alternate ending carries the same message as that of the theatrical version, "the denial of otherness," because Neville recognizes the alpha male's humanity only through his "monogamous heterosexual bonding" (181). However, the proceeding point-of-view shot of the photos of deceased test subjects suggests that Neville realizes that the border between the infected and himself is more unstable than he wanted to believe, and that maybe it is he who has been a monster all along. The alternate ending brings the significance of Neville as a "legend" close to its original meaning in Matheson's novel-namely, the legend of the killer of the infected, the new race on earth. ${ }^{x v}$

${ }_{39}$ The theatrical version of the film ends with Anna's arrival at the survivors' colony. The colony suggests the recovery of the once lost American homeland, only far more upgraded, with better security and traditional "American" values to unify its citizens as a nation. As Hantke points out, "The 'colony' up in Vermont is permanently protected by the things Neville is missing: genuine family life, a higher fence, religion, and a well-organized military" (169). The fact that Anna is welcomed into this gated community of sorts raises a question: who is and who is not accepted into this utopian community when we interpret I Am Legend as an allegory of post-9/11 America?

${ }_{40}$ Anna's acceptance into the colony has an important symbolic meaning as a gesture to maintain American identity as a nation of immigrants. Since the post-civil rights era, the national leaders had been building up official 
multiculturalist discourses that celebrated diversity and the end of racism as a result of outlawing color-based segregation, and re-imagined the national identity as a "nation of immigrants." xvi The boundaries that the DHS and ICE tried to draw to safeguard America as one nation contradicted the national myth of official multiculturalism. The myth stated that the United States righted the wrongs of the past and became a country that guarantees freedom and equal, colorblind opportunity to everyone in society; however, this myth went hand-in-hand with a nationalism that, while officially colorblind, was nationalistic nonetheless. America has to close its borders for the sake of homeland security, but it must not be closed to everybody.

${ }_{41}$ The last scene suggests that America still welcomes legitimate immigrants with open arms, as Anna is greeted by the residents of the colony as soon as she passes the gate. What makes Anna legitimate is certainly her immunity to the virus, but what differentiates her from the infected is not simply her blood. She speaks English, with a slight Brazilian accent but well enough to communicate with Neville. Most of all, it is important that she is a Christianand not just a Christian, but a bacon-eating Christian who considers bacon, the forbidden food to Muslims, as "the most fantastic thing in history." It may not be a significant detail, but bacon does receive an unnecessary spotlight in that scene through Neville's excuse about his angry acting out. The audience knows that he is not upset simply because he has been "saving that bacon," as he says, but he repeats the excuse twice. Anna's nationality is not a random choice but a careful one in the context of colorblind nationalism that is fundamentally harmonizing with official multiculturalism, as both deny the urgency of racism and endorse the myth of post-racial America. Brazil was a safe choice because compared to Mexicans, Brazilians (though from Latin America) are officially defined as non-Hispanic and non-Latino on the U.S. census (Marrow 431). Despite the fact that by 2005, "Brazilians were among the top five among deportees, nearly all of whom were deported for illegal presence in the United States" (Golash-Boza 31), during the time of "intensified anti-Latina/o xenophobia" (Fusté 814), a Brazilian may sound less threatening than someone from Central America, where most undocumented laborers came from and most social fears were directed toward. Brazil also has a reputation as a racial paradise where all races are equal and coexist, and having a character from such a diverse place may help the film maintain the façade of colorblindness. 
${ }_{42}$ Anna leads the religious subtext of the film and adds a religious dimension to Neville's final action. She helps Neville make a conversion from science and skepticism to Christianity, "listening" to God and sacrificing himself at the end of the film. ${ }^{\text {vii }}$ She knows that there is a survivors' camp because "God told [her]" so, and at the end of the film, we see that she has been right about "God's plan." The very first thing we notice about her is the cross hanging on the rear-view mirror of her car. We may assume that she is Catholic because she is from São Paulo, but in the film, she is more of a "Christian" in a broad sense; we do not know for certain what her denomination is, as any sign of Catholicism has been deliberately removed from the film. When Anna, Ethan, and Neville are about to have breakfast, the camera shows only Neville, so we do not see whether Anna makes the sign of the cross as a Catholic might. Additionally, all of the scenes that took place in St. Patrick's Cathedral were deleted. Just as Neville's blackness has become insignificant in colorblind post-9/11 America, Anna's Catholicism becomes assimilated with Christianity, alluding to its opposition against Islam.

\section{Conclusion}

43 Lawrence's I Am Legend, with its loose plot and inconsistent use of symbols, xvii is a film that can be criticized on many levels. However, it is significant when considered in the context of post-9/11 American homeland security and colorblind nationalism because it carries many signs of the repression involved in the act of dividing "us" and "them," and of creating a stateless population within the borders of the United States. Replacing all racial markers with geographical markers, the film foregrounds a black hero and pale monsters to represent "us" and "them," respectively - that is, America as a nation-state and all of the threats to American homeland security. The South Street Seaport scene manifests a newly drawn border within the state. The precarious method of drawing a line between the infected and the uninfected reminds us of the immigrant eye exams at Ellis Island in the early twentieth century. The infected, a hybrid species between vampires and zombies who populate the Meatpacking District, signify the stateless within the United States, who somehow cannot claim the United States as their homeland and who are rendered "foreign" and thus considered threats to the 
nation. Neville's lonely quest to find a vaccine and cure the infected corresponds with the desire to recover the homeland that was supposedly lost in the 9/11 attacks; it also reflects dreams to rebuild a nation-state that safeguards its unity by drawing and redrawing the border between "us" and "them" in a way that hides the precariousness of this distinction. The infected, "quarantined" in the "thirdworldified" jungle of Manhattan, are the abjects of the post-9/11 America, expelled from the newly imagined nation but haunting the ghettoized city of New York.

\section{BIBLIOGRAPHY}

Alden, Edward. The Closing of the American Border: Terrorism, Immigration, and Security since 9/11. New York: Harper, 2008. Print.

Balibar, Etienne, and Immanuel Wallerstein. Race, Nation, Class: Ambiguous Identities. London: Verso, 1991. Print.

Berger, James. After the End: Representations of Post-apocalypse. Minneapolis: U of Minnesota P, 1999. Print.

Boyle, Kirk. "Children of Men and I Am Legend: The Disaster-capitalism Complex Hits Hollywood." Jump Cut: A Review of Contemporary Media. (n.d.) Web. 14 Jan. 2013. < http:// www.ejumpcut.org/archive/jc51.2009/ChildrenMenLegend/ text.html.

Brayton, Sean. "The Racial Politics of Disaster and Dystopia in I Am Legend.” The Velvet Light Trap 67 (2011): 66-76. Print.

Bush, George W. “The President's State of the Union Address.” 29 Jan. 2002. Web. 10 Oct. 2014. hhttp://georgewbush-whitehouse.archives.gov/news/ releases/2002/01/20020129-11.html.

Butler, Judith, and Gayatri Chakravorty Spivak. Who Sings the Nation-State? Language, Politics, Belonging. Calcutta, India: Seagull Books, 2010. Print.

Bynum, Russ. "Immigration Raid Devastates Ga. Town.” The Boston Globe. 16 Sept. 2006. Web. 15 Nov. 2014. «http://www.boston.com/news/nation/articles/ 2006/09/16/immigration_raid_devastates ga town/>.

Cainkar, Louis A. Homeland Insecurity: The Arab American and Muslim American Experience after 9/11. Thousand Oaks: Sage, 2009. JSTOR. Web. 24 Oct. 2014. 
Chertoff, Michael. "Law, Loyalty, and Terror." The Weekly Standard. 1 Dec. 2003. Web. 21 Dec. 2012. <http://www.weeklystandard.com/Content/Public/ Articles/000/000/003/419jwsgm.asp?.

DiNapoli, Thomas P., and Kenneth B. Bleiwas. "The Role of Immigrants in the New York City Economy." Office of the State Comptroller Report 17-2010. New York City Public Information Office. Jan. 2010. Web. 28 Dec. 2012.

\section{https://www.osc.state.ny.us/osdc/rpt17-2010.pdf .}

Fusté, José I. “Containing Bordered 'Others' in La Frontera and Gaza: Comparative Lessons on Racializing Discourses and State Violence.” American Quarterly 62 (2010): 811-19. Print.

Golash-Boza, Tanya Maria. Immigration Nation: Raids, Detentions, and Deportations in Post-9/11 America. Boulder, CO: Paradigm Publishers, 2012. Print.

Goldsman, Akiva. "Creating I Am Legend." I Am Legend. Dir. Francis Lawrence. 2 Disc Special Edition. 2008. DVD.

Hantke, Stephen. "Historicizing the Bush Years: Politics, Horror Film, and Francis Lawrence's I Am Legend." Horror after 9/11: World of Fear, Cinema of Terror. Ed. Aviva Briefel and Sam J. Miller. Austin: U of Texas P, 2011. 165-85. Print.

Hoefer, Michael, Nancy Rytina, and Bryan Baker. "Estimates of the Unauthorized Immigrant Population Residing in the United States: January 2011." Population Estimates. Department of Homeland Security. March 2012. Web. 9 Aug. 2013. <http://wWW.dhs.gov/ estimates-unauthorized-immigrant-population-residingunited-states-january-2011.

Höglund, Johan. The American Imperial Gothic: Popular Culture, Empire, Violence. Dorchester: Ashgate, 2014. Print.

Homberger, Eric. The Historical Atlas of New York City. $2^{\text {nd }}$ ed. New York: Holt Paperbacks, 2005. Print.

Huges, David. The Greatest Sci-fi Movies Never Made. Rev. ed. London: Titan Books, 2008. Print. Kandel, William A. "The U.S. Foreign-Born Population: Trends and Characteristics." Congressional Research Service. 18 Jan. 2011. Web. 5 Jan. 2013. <http://fas.org/sgp/ crs/misc/R41592.pdf>.

Kaplan, Amy. "Homeland Insecurities: Reflections on Language and Space.” Radical History Review 85 (2003): 82-93. Print.

---. "Violent Belongings and the Question of Empire Today: Presidential Address to the American Studies Association, October 17, 2003.” American Quarterly 56.1 (2004): 1-18. Print.

Kim, Claire Jean. "Imagining Race and Nation in Multiculturalist America." Ethnic and Racial Studies 27 (2004): 987-1005. Print.

---. “The Racial Triangulation of Asian Americans." Politics \& Society 27 (1999): 105-38. Print. Kristeva, Julia. Powers of Horror: An Essay on Abjection. Trans. Leon S. Roudiez. New York: Columbia UP, 1984. Web. 21 oct. 2014. <http://seas3.elte.hu/coursematerial/ RuttkayVeronika/Kristeva - powers of horror.pdf.

Lawrence, Francis dir. I Am Legend. 2007. DVD. 
Levine, John. "US: Children Left Abandoned by Factory Immigration Raid.” World Socialist Website. 5 Aug. 2005. Web. 15 Nov. 2014. http://www.wsws.org/en/articles/ 2005/08/raid-a05.html.

Markee, Patrick. "New Federal Data Confirms Rising Homeless Population in New York." Coalition for the Homeless. 26 Apr. 2011. Web. 28 Dec. 2012. <http:// www.coalitionforthehomeless.org/wp-content/uploads/ 2014/06/BriefingPaperNewFederalDataConfirmsRiseinNYHomelessness4-26-2011.pdf?.

Marrow, Helen. “To Be or Not to Be (Hispanic or Latino): Brazilian Racial and Ethnic Identity in the United States." Ethnicities 3 (2003): 427-64. Print.

Matheson, Richard. I Am Legend. 1954. New York: Tom Doherty Associates, 1995. Print.

McConnell, Mariana. "Interview: George A. Romero on Diary of the Dead." Cinema Blend. 14 Feb. 2008. Web. 20 Nov. 2014. < http://www.cinemablend.com/new/ Interview-George-A-Romero-On-Diary-Of-TheDead-7818.html.

Nafziger, James A. R. "Immigration and Immigration Law after 9/11: Getting It Straight.” Denver Journal of International Law and Policy 37 (2009): 555-65. Print.

Nama, Adilifu. Black Space: Imagining Race in Science Fiction. Austin: U of Texas P, 2010. JSTOR. Web. 15 Oct. 2014.

“New York City Demographic Shifts, 2000 to 2010." Center for Urban Research at CUNY. n.d. Web. 5 Jan. 2013. < http://www.urbanresearchmaps.org/plurality/>.

"Over-raided, Under Siege: U.S. Immigration Laws and Enforcement Destroy the Rights of Immigrants." Human Rights Network. Jan. 2008. Web. 30 Oct. 2014. <http:// 173.236.53.234/ nnirrorg/drupal/sites/default/files/ undersiege web.pdf .

Patterson, Kathy D. "Echoes of Dracula: Racial Politics and the Failure of Segregated Spaces in Richard Matheson's I Am Legend.” Dracula Studies 7 (2005): 19-27. Print.

"Physical Examination of Female Immigrants at Ellis Island, New York City." 1911. Library of Congress. Web. 20 Dec. 2012. < http://wWw.loc.gov/pictures/item/ 95506353/>.

Randall, Kate. "US Immigration Agents Arrest 1,282 in Raids at Six Meatpacking Plants." World Socialist Website. 14 Dec. 2006. Web. 15 Nov. 2014. <http://WWW.WSWS.org/en/ articles/2006/12/raid-d14.html>.

Sassen, Saskia. The Global City: New York, London, Tokyo. $2^{\text {nd }}$ ed. Princeton: Princeton UP, 2001. Print.

Sides, Josh. "Straight into Compton: American Dreams, Urban Nightmares, and the Metamorphosis of a Black Suburb.” American Quarterly 56 (2004): 583-605. Print.

Stephen, Michelle A. “Babylon's 'Natural Mystic': The North American Music Industry, the Legend of Bob Marley, and the Incorporation of Transnationalism." Cultural Studies 12.2 (1998): 139-67. Print.

Subramanian, Janani. “Alienating Identification: Black Identity in The Brother from Another Planet and I Am Legend.” Science Fiction Film and Television 3.1 (2010): 37-56. Print. 
Tashima, A. Wallace. “Play It Again, Uncle Sam.” Keynote Address for "Judgments Judged and Wrongs Remembered: Examining the Japanese American Civil Liberties Cases of World War II on Their Sixtieth Anniversary." 2005. Web. 10 Oct. 2014. < http://

scholarship.law.duke.edu/cgi/viewcontent.cgi? article $=1348 \&$ context $=$ lcp .

The Last Man on Earth. Dir. Ubaldo Ragona. 1964. DVD.

The Omega Man. Dir. Boris Sagal. 1971. DVD.

Wald, Priscilla. Contagious: Cultures, Carriers, and the Outbreak Narrative. Durham: Duke UP, 2008. Print.

Wenk, Christian. Abjection, Madness and Xenophobia in Gothic Fiction. Berlin: WVB, 2008. Print.

Wetmore, Kevin J. Jr. Post-9/11 Horror in American Cinema. New York: The Continuum International Publishing Group, 2012. Print.

\section{NOTES}

i. This work was supported by the National Research Foundation of Korea Grant funded by the Korean Government (NRF-2013S1A2A1A01033982).

ii. On the dual process of producing a national community, see Etienne Balibar's Race, Nation, Class: Ambiguous Identities, 93-100.

iii. Many American citizens have also been subject to detainment (ex. José Padilla, Yaser Esam Hamdi, Davino Watson) and deportation (ex. Mark Lyttle, Pedro Guzman). American citizens whose loyalty to the United States was in question have also been subject to charges of espionage as seen from the case of James Yee, a Muslim Chinese American chaplain at Guantanamo Bay detention camp. Citizens who are critical to the War on Terror have been repeatedly harassed, such as in the case of Laura Poitras, a U.S. filmmaker and journalist who made a trilogy of the War on Terror, who has been detained and interrogated at airports almost every time she returned to the U.S. Citizen Four, Poitras's 2014 documentary on Edward Snowden, was filmed under extreme security and had to be edited in Germany in fear of intervention by the DHS.

iv. According to Julia Kristeva, an abject is the "jettisoned object" that safeguards the homologous self, which marks a border of the self but at the same time disturbs the border because an abject is "myself" expelled as not-me. I made an analogy between Kristeva's abject and an abject of a nation-state because a nation, to produce a peoplehood, has to exclude certain groups of people as outsiders.

v. A "geographical marker" usually refers to a natural geographic feature, such as a tree, river, or lake, or to a visual representation of location information in computer mapping 
products. In this essay, a geographical marker is a notion parallel to a "racial marker": a visual representation of a location that functions as a marker of its inhabitants' identity.

vi. The lives of Arab and Muslim Americans who were detained as terrorist suspects were stigmatized even after being released with no charge. Their clients, customers, colleagues, and other community members avoided any contact with the former detainees because "'contact' has been used as evidence of aiding and abetting terrorism” (Cainkar 122).

vii. Amy Kaplan points out that homeland "has a connection to the discourse of diaspora and exile, to a sense of loss, longing, and nostalgia. In this meaning, homeland may evoke a sense not of stability and security, but of deracination and desire. The idea of America as aspiring to a lost homeland depends on evoking terrorism as the constant threat to sever Americans from their legitimate aspirations. Thus the idea of the homeland works by generating a profound sense of insecurity" ("Violent Belongings" 9).

viii. Protosevich wrote a screenplay in 1995, but Ridley Scott replaced him with Logan, who wrote another version in 1997. Warner Brothers, however, cancelled the project due to its lack of commercial appeals.

ix. New York City is also a showcase for inter-group segregation. For example, there is segregation between African-Americans and Afro-Caribbeans and between Dominicans and Puerto Ricans. These "patterns of segregation...correspond to a hierarchy of spaces in terms of household income" (Sassen 265). As Sassen points out, race and immigration status are not the only factors that affect the patterns of segregation. Household income is another important factor: after decades of gentrification, New York-especially Manhattan, where the price of real estate has soared due to the residential preference of professionals with high incomes-is short on affordable housing for the poor. New York has one of the highest homeless populations in the United States, with more than 50,000 people living in shelters in 2009 and 2010 (Markee)-a number that does not include the "invisible" homeless, who do not seek help in shelters.

x. The motif of eye scanning is extensively used in the film Blade Runner (1982). The "Voight-Kampff" test monitors the subject's eye to see whether or not the subject shows empathic responses. However, the border between human and non-human in the film is challenged through the introduction of the replicants, which are deemed "more human than human."

xi. Popular genres such as online novels and TV shows still portrayed the Meatpacking District as a place for prostitution, crime, and immigrants. The main character in Monster Island 
(2004), an online zombie novel set in Manhattan, finds Western Beef, a supermarket known for its display of carcasses hanging on hooks, and a dance club called Lotus, "another kind of meat market" (Chapter 14), both of which were closed by the time the book was published in 2006. In the television show Law \& Order: Special Victims Unit, victims and criminals are often found in the Meatpacking District. Indeed, when WNYC mapped out all of the shooting locations from Seasons 1 to 13, the Meatpacking District was found to be one of the most frequently used, featured in 11 episodes ("Every Law and Order: SVU Location Mapped!").

xii. I Am Legend has an alternate ending that is radically different from that of the theatrical version: Neville realizes that the infected are attacking his house to find the alpha male's female companion. After seeing that the alpha male and the female test subject are happy to be reunited, Neville apologizes to them. The infected leave Neville intact, and he heads for the survivors' colony with Anna and Ethan.

xiii. Immigrant labor has been largely used to keep wages low in the meatpacking industry, and the company towns of the meatpacking industry have become major targets of ICE worksite raids. On July 26, 2005, 119 workers for the Petit Jean Poultry plant were arrested in Arkadelphia, Arkansas (Levine). More than 120 people were arrested at the Crider Inc. poultry plant on September 1, 2006 (Bynum). One of the largest worksite raids was at Swift Meatpacking Co. in Greeley, Colorado on December 12, 2006, which resulted in arrests of 262 employees (GolashBoza 52-54). Other raids at Swift plants made much more arrests in the same year: there were 145 arrests in Hyrum, Utah, 230 arrests in Worthington, Minnesota, 90 arrests in Marshaltown, Iowa, 261 arrests in Grand Island, Nebraska, and 295 arrests in Cactus, Texas (Randall).

xiv. George Romero cited the novel, I Am Legend, as inspiration for his film: "When I did Night of the Living Dead I called them ghouls, flesh eaters. To me back then, zombies were just those boys in Caribbean doing the wet-work for Bela Lugosi. So I never thought of them as zombies. I thought they were just back from the dead. I ripped off the idea for the first film from a Richard Matheson novel called I Am Legend" (McConnell, "Interview").

xv. Like Neville in Matheson's novel, Neville in the film has also been a cold-hearted killer of the infected. In an earlier scene, Neville shows no sign of sympathy at all when he says the new compound he is experimenting with the kidnapped female test subject will "certainly kill it." To Anna's exclamation, "oh, God," on hearing about the deaths of the test subjects whose photos cover a wall of the lab, Neville responds, "God didn't do this. We did." For him, the test subject on the table is not human but "it," 
and it is not him who killed all of them, but "we" are responsible for their deaths.

xvi. The House of Representatives passed the Congressional resolution in 1999, which defines the United States as a "nation of immigrants" ("A Congressional Resolution to Celebrate One America" quoted in Kim, "Imagining Race and Nation in Multiculturalist America" 1044). On the official multiculturalist discourse in relation with triumphalist narratives, see Kim's same article, 198-93.

xvii. See Kirk Boyle's "Children of Men and I Am Legend" to read more about the religious subtext of the film and Anna's fundamentalism.

xviii. The motif of the butterfly, for example, becomes meaningful only with the alternative ending, in which Neville makes a connection between butterfly images throughout the film-the butterfly drawn on the glass by the alpha male, the tattoo on the shoulder of the female test subject, and the butterfly that his daughter made (the very last image of his daughter.) Listening to his daughter's call to "look at the butterfly," Neville recognizes the female test subject's individuality and his misunderstandings about the infected. In the theatrical version, the butterfly motif loses its symbolic power and ends up merely as an object of Neville's daughter's childish play, which does not gain much symbolic meaning from the butterflies that are seen flying around Sam in Times Square.

\section{ABSTRACTS}

This essay attempts to place I Am Legend (2007) in the context of American nationalism and aggressive enforcement of the immigration laws after 9/11. The apocalyptic world of I Am Legend reflects the post-9/11 American society that is driven by the urge to make America "one nation" and haunted by the fear of people who might harm the "unity." The film tries to draw a clear boundary between "us" and "them" by completely othering the infected, but in the context of American homeland security after 9/11, it becomes a complex issue to decide where to draw the line. The shifty boundary between "us" and "them" reflects the post-9/11 American dilemma: the United States has to close its border while maintaining its identity as a nation of immigrants. This essay also discusses how geographical markers, instead of racial markers, are utilized to symbolize the infected as the stateless people within the United States. 
INDEX

Keywords: colorblind nationalism, homeland security, immigration, nation-state, New York City Mots-clés: Akiva Goldsman, Bob Marley, Francis Lawrence, John Logan, Mark Protosevich, Richard Matheson, Will Smith

\section{AUTHOR}

EUNJU HWANG

Sogang University 